\title{
Regulation of the motility of fowl spermatozoa by calcium and CAMP
}

\author{
G. J. Wishart* and K. Ashizawa $\dagger$ \\ AFRC Institute of Animal Physiology and Genetics Research, Edinburgh Research Station, Roslin, \\ Midlothian EH25 9PS, U.K.
}

\begin{abstract}
Summary. Using an objective light-scattering technique, it was confirmed that washed fowl spermatozoa become immotile as the temperature is raised from $30^{\circ} \mathrm{C}$ to the normal body temperature of $4041^{\circ} \mathrm{C}$. Motility of washed spermatozoa was restored at $40^{\circ} \mathrm{C}$ by the addition of caffeine or calcium, both stimulating motility to a maximum in a dose-dependent manner. Neither effector stimulated the motility of spermatozoa at $30^{\circ} \mathrm{C}$. Caffeine, but not calcium, caused an increase in sperm cAMP levels at $40^{\circ} \mathrm{C}$. The concentrations of calcium and cAMP in untreated spermatozoa were not significantly different in samples incubated at $30^{\circ} \mathrm{C}$ or $40^{\circ} \mathrm{C}$.
\end{abstract}

\section{Introduction}

Fowl spermatozoa, when suspended in a simple salt-based medium, become immotile as the incubation temperature is raised to $41^{\circ} \mathrm{C}$, the normal avian body temperature (Munro, 1938; Nevo \& Schindler, 1968; Ashizawa \& Nishiyama, 1978; Takeda, 1982). Motility can be restored by lowering the temperature again (e.g. Takeda, 1982) or by the addition of body fluids, such as seminal plasma (e.g. Nevo \& Schindler, 1968). The following work was designed to investigate this phenomenon more rigorously by using an objective assay of the motility of fowl spermatozoa (Wishart \& Ross, 1985) and chemically-defined effectors of motility.

\section{Materials and Methods}

Animals and semen collection. Male fowls were from a Rhode Island Red control strain from Ross Breeders Ltd, Newbridge, Midlothian. They were caged individually, given $14 \mathrm{~h} \mathrm{light} / 24 \mathrm{~h}$ and fed a commercial breeders ration ad libitum. Semen was collected free from transparent fluid (Lake, 1957) on a 3 times weekly routine. Only males consistently producing spermatozoa with high motility (see Wishart \& Palmer, 1986) were used as semen donors.

Preparations of spermatozoa. Semen was diluted 8 -fold in $0.15 \mathrm{M}$ - $\mathrm{NaCl}$ with $20 \mathrm{mM}$-TES ( $N$-Tris-[hydroxymethyl]methyl-2-aminoethanesulphonic acid) at $\mathrm{pH} 7.4$ and centrifuged at $700 \mathrm{~g}$ for $12 \mathrm{~min}$ at room temperature. The washed spermatozoa were reconstituted in the same buffer to give a final concentration of approximately $1 \times 10^{9} \mathrm{cells} / \mathrm{ml}$. Samples of $2-4 \mathrm{ml}$ were incubated aerobically in $25 \mathrm{ml}$ 'Nalgene' flasks.

Assays. Sperm motility was assayed as described by Wishart \& Ross (1985), but substituting the NaCl/TES buffer described above. The constant, $\%(\Delta \mathrm{OD})_{\mathrm{m}}$, which correlates with the percentage of motile spermatozoa (Wishart \& Ross, 1985), was used to describe 'motility'. Numbers of spermatozoa were established from the constant $\mathrm{OD}_{\mathrm{m}}$.

ATP concentrations in spermatozoa were assayed in boiled extracts (Wishart, 1982). cAMP was estimated in similarly-prepared extracts by a commercially-available protein-binding assay kit (The Radiochemical Centre, Amersham, Bucks, U.K.). Intracellular levels of $\mathrm{Ca}^{2+}$ were measured in samples centrifuged in a Beckman 'Microfuge' $(10000 \mathrm{~g})$ for $30 \mathrm{sec}$. The pellet, including a portion of trapped supernatant, was resuspended in $0 \cdot 1 \mathrm{M}-\mathrm{HCl}$. After

*Present address: Department of Molecular and Life Sciences, Dundee College of Technology, Bell Street, Dundee DDI IHG, U.K.

†Present address: Laboratory of Animal Reproduction, Faculty of Agriculture, Miyazaki University, Miyazaki 88921, Japan. 
storage at $5^{\circ} \mathrm{C}$ and centrifugation, the acidic supernatants of these samples were assayed for $\mathrm{Ca}^{2+}$ by atomic absorption spectroscopy. To assess the quantity of incubation medium in each pellet, samples containing $1 \%$ bovine serum albumin were incubated and centrifuged in parallel with test samples. These pellets were resuspended in medium without albumin and recentrifuged. The protein content of the secondary supernatant was compared with that of the original supernatant by the method of Lowry et al. (1951) and the extracellular space in each pellet was calculated.

\section{Results}

The effects of increasing concentrations of calcium and caffeine on the motility of fowl spermatozoa at $40^{\circ} \mathrm{C}$ are shown in Fig. 1. Calcium appeared to be more potent, stimulating motility to a maximum of $65.6 \pm 2.9 \%$ compared with $46.9 \pm 3.7 \%$ for caffeine. At each concentration, the effect of calcium and caffeine in combination was greater than that of calcium alone and at low concentrations $(0.2$ and $0.5 \mathrm{mM})$ their combined effects were aproximately additive.

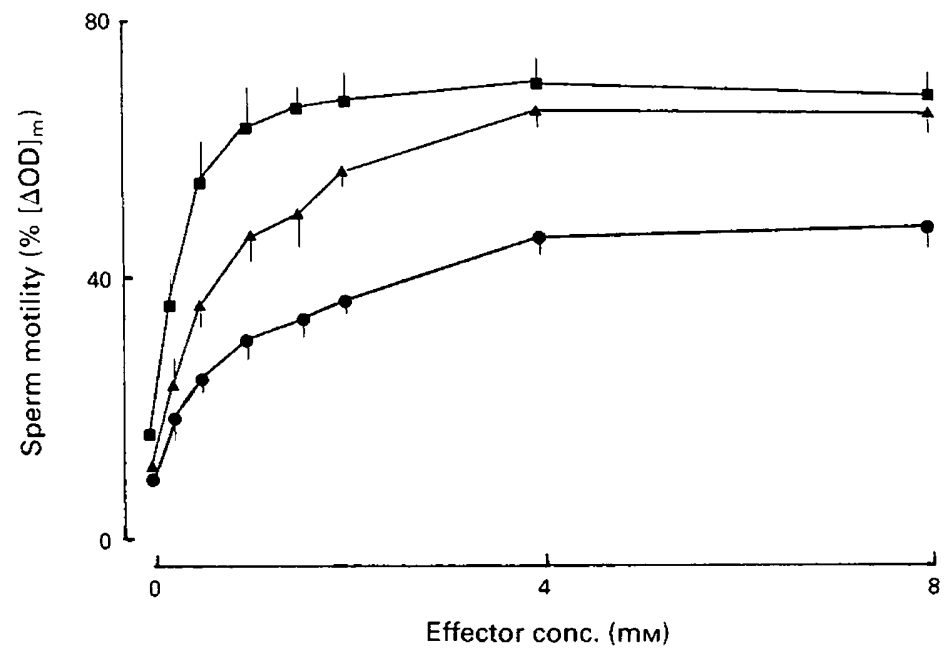

Fig. 1. The effect of caffeine and calcium on the motility of fowl spermatozoa at $40^{\circ} \mathrm{C}$. Three samples of spermatozoa were assayed for motility approximately $20 \mathrm{sec}$ after the addition of each effector at each concentration. Points represent the mean ( \pm s.e.m.) motility of samples with added caffeine $(\bullet)$, calcium $(\boldsymbol{\Delta})$ and caffeine + calcium $(\boldsymbol{\square})$.

The lack of increase of response to effector at concentrations greater than $4 \mathrm{~mm}$ was not, apparently, associated with a limitation of available energy: ATP concentrations of 3 samples ( \pm s.e.m.) in buffer only, with $8 \mathrm{~mm}$-caffeine and with $8 \mathrm{~mm}$-calcium, were $34 \cdot 4 \pm 1 \cdot 9,27 \cdot 2 \pm 2 \cdot 1$ and $25.8 \pm 0.6 \mathrm{nmol} / 10^{9}$ spermatozoa, respectively.

Figure 1 shows the stimulation of motility within $15-20 \mathrm{sec}$ of the addition of each effector. The effect of more prolonged exposure is shown in Fig. 2. Stimulation by caffeine was of a short duration (2-3 min) compared with that by calcium. At $30^{\circ} \mathrm{C}$, no significant stimulation (Student's $t$ test, $P \geq 0.05$ ) of motility by caffeine or calcium could be shown: for $8 \mathrm{~mm}$ of each effector, the mean ( \pm s.e.m.) motility of 4 samples was $76 \pm 3 \%$ with added calcium, and $79 \pm 2 \%$ with added caffeine, compared to $83 \pm 3 \%$ for untreated samples. Both calcium and caffeine have been considered to stimulate sperm motility by their action on cyclic nucleotide metabolism (see Garbers \& Kopf, 1980; Tash \& Means, 1983). Although caffeine could be shown to induce an increase in sperm cAMP concentrations, calcium was quite ineffective (Fig. 3). As the temperature was raised 


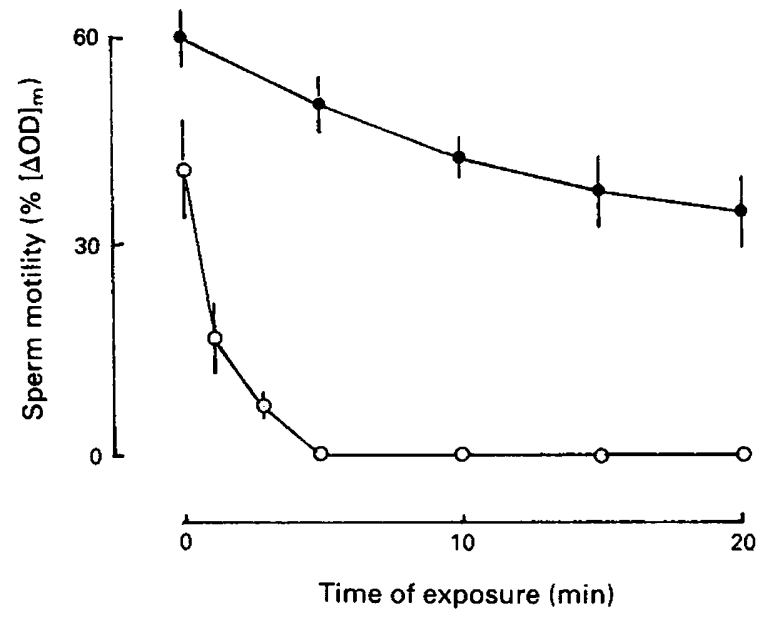

Fig. 2. The time course of motility stimulation by caffeine and calcium. Each point represents the mean $( \pm$ s.e.m. $)$ motility of three samples of spermatozoa after the addition of $2 \mathrm{~mm}$ caffeine $(O)$ or calcium $(O)$.

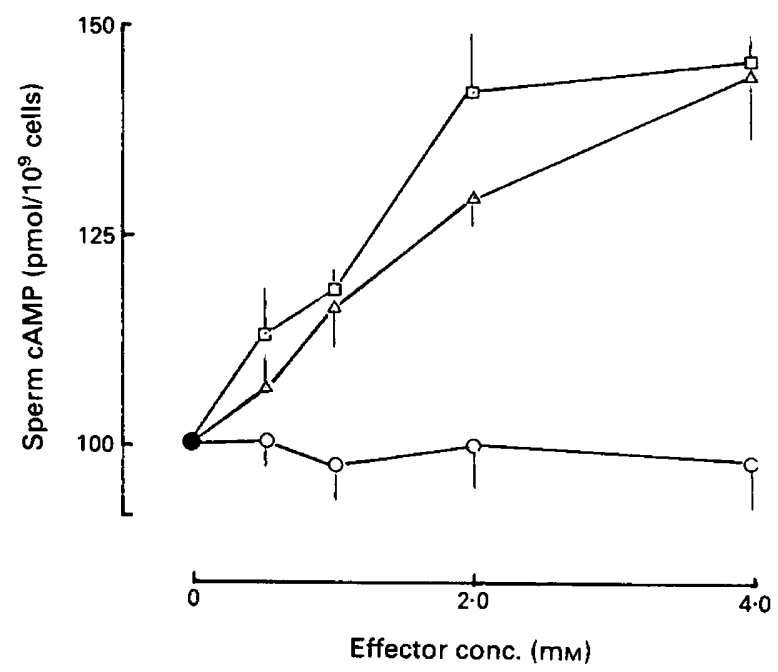

Fig. 3. The effect of caffeine and calcium on fowl sperm cAMP concentrations. The mean ( \pm s.e.m.) concentrations of cAMP in 3 suspensions are expressed as a percentage of control (no additions) levels following the addition of caffeine $(\triangle)$, calcium $(O)$ or caffeine + calcium ( $\square$ ). Control cAMP concentrations were $103 \pm 5 \mathrm{pmol} / 10^{9}$ spermatozoa.

from 30 to $40^{\circ} \mathrm{C}$, the mean ( \pm s.e.m.) motility of 5 samples of fowl spermatozoa fell from $78 \cdot 9 \pm 7 \cdot 5 \%$ to $9 \cdot 7 \pm 2 \cdot 7 \%$. However, sperm cAMP concentrations in samples incubated at 30 and $40^{\circ} \mathrm{C}$ were, at levels of $94 \pm 9$ and $93 \pm 9$ pmol cAMP per $10^{9}$ spermatozoa, respectively, not significantly different (Student's $t$ test, $P \geq 0.01$ ); nor were the sperm concentrations of calcium, at $130 \pm 6$ and $126 \pm 6 \mathrm{nmol} / 10^{9}$ spermatozoa, respectively. 


\section{Discussion}

Methylxanthines such as caffeine have been shown to stimulate the motility of spermatozoa of many vertebrate and invertebrate species (see Garbers \& Kopf, 1980). This effect has been mainly attributed to a rise in sperm cAMP levels (Garbers et al., 1971, 1973; Hoskins et al., 1975) resulting from the property of these compounds to inhibit cAMP phosphodiesterase (see Jost \& Rickenberg, 1971).

The effect of calcium on sperm motility is, however, less straightforward. Depending on the species, calcium may stimulate (Morita \& Chang, 1970; Young \& Nelson, 1974; Davis, 1978; Cooper, 1984), inhibit (Bredderman \& Foote, 1971; McGrady et al., 1974) or have little effect (Quinn et al., 1970; Hyne \& Garbers, 1979). Most evidence suggests that stimulation of motility by calcium is mediated through cyclic nucleotide metabolism since calcium involves a rise in sperm cAMP concentrations (Hyne \& Garbers, 1979; Kopf \& Garbers, 1980; Kopf et al., 1983) and can be shown to activate adenylate cyclase activity in broken cell preparations of spermatozoa (Braun, 1975; Hyne \& Garbers, 1979; Hyne \& Lopata, 1982; Kopf \& Vacquier, 1984). However, calcium does have a more direct effect on phosphorylation of motility-associated proteins in both actin(Aldestein \& Eisenberg, 1980) and tubulin- (Schulman, 1985) based systems. The present work offers the first evidence in spermatozoa of an effect of calcium on motility in the absence of any demonstrable change in cyclic nucleotide metabolism.

The inhibition of motility of fowl spermatozoa which occurs as the temperature is raised from 30 to $40^{\circ} \mathrm{C}$ could not be shown to be associated with a change in the cellular concentration of cAMP or calcium. If, as with spermatozoa of other species, calcium and cAMP are the main regulators of fowl sperm motility, then this anomalous temperature-dependent inhibition is probably the result of different compartmentation of these effectors.

We thank the AFRC Underwood Fund for financial assistance to K.A. and Dr P. E. Lake for helpful discussion.

\section{References}

Aldestein, R.S. \& Eisenberg, E. (1980) Regulation and kinetics of the actin-myosin-ATP interaction. Ann. Rev. Biochem. 49, 921-956.

Ashizawa, K. \& Nishiyama, H. (1978) Effects of temperature on the vigour of motility, oxygen consumption and duration of motility of fowl spermatozoa under aerobic conditions. Jap. Poult. Sci. 15, 264-266.

Braun, T. (1975) The effect of divalent cations on bovine spermatozoal adenylate cyclase activity. J. cyclic Nucleotide Res. 1, 271-281.

Bredderman, P.J. \& Foote, R.H. (1971) The effect of calcium ions on cell volume and motility of bovine spermatozoa. Proc. Soc. exp. Biol. Med. 137, 1440-1443.

Cooper, T.G. (1984) The onset and maintenance of hyperactivated motility of spermatozoa from the mouse. Gamete Res. 9, 55-74.

Davis, B.K. (1978) Effect of calcium on motility and fertilisation by rat spermatozoa in vitro. Proc. Soc. exp. Biol. Med. 157, 54-56.

Garbers, D.L. \& Kopf, G.S. (1980) The regulation of spermatozoa by calcium and cyclic nucleotides. $A d v$. cyclic Nucleotide Res. 13, 251-307.

Garbers, D.L., Lust, W.D., First, N.L. \& Lardy, H.A. (1971) Effects of phosphodiesterase inhibitors and cyclic nucleotides on sperm respiration and motility. Biochemistry, N.Y. 10, 1825-1831.

Garbers, D.L., First, N.L. \& Lardy, H.A. (1973) The stimulation of bovine epididymal sperm metabolism by cyclic nucleotide phosphodiesterase inhibitors. Biol. Reprod. 8, $589-598$.

Hoskins, D.D., Hall, M.L. \& Munsterman, D. (1975) Induction of motility in immature bovine spermatozoa by cyclic AMP phosphodiesterase inhibitors and seminal plasma. Biol. Reprod. 13, 168-176.

Hyne, R.V. \& Garbers, D.L. (1979) Calcium-dependent increase in adenosine $3^{\prime}, 5^{\prime}$-monophosphate and induction of the acrosome reaction in guinea pig spermatozoa. Proc. natn. Acad. Sci. U.S.A. 76, 5699-5703.

Hyne, R.V. \& Lopata, A. (1982) Calcium and adenosine affect human sperm adenylate cyclase activity. Gamete Res. 6, 81-89.

Jost, J.P. \& Rickenberg, H.V. (1971) Cyclic AMP. Ann. Rev. Biocem. 40, 741-774.

Kopf, G.S. \& Garbers, D.L. (1980) Calcium and a fucosesulfate-rich polymer regulate sperm cyclic nucleotide metabolism and the acrosome reaction. Biol. Reprod. 22, 1!18-1126.

Kopf, G.S. \& Vacquier, V.D. (1984) Characterisation of 
a calmodulin-stimulated adenylate cyclase from abalone spermatozoa. J. biol. Chem. 259, 7590-7596.

Kopf, G.S., Lewis, C.A. \& Vacquier, V.D. (1983) Regulation of abalone sperm cyclic AMP concentrations and the acrosome reaction by calcium and methylxanthines. Devl. Biol. 98, 28-36.

Lake, P.E. (1957) Fowl semen as collected by the massage method. J. agric., Sci., Camb. 49, 120-126.

Lowry, O.H., Rosebrough, H.J., Farr, A.L. \& Randall, R.J. (1951) Protein measurement with the folin phenol reagent. J. biol. Chem. 193, 265-275.

McGrady, A.V., Nelson, L. \& Ireland, M. (1974) Ionic effects on the motility of bull and chimpanzee spermatozoa. J. Reprod. Fert. 40, 71-76.

Morita, Z. \& Chang, M.C. (1970) The motility and aerobic metabolism of spermatozoa in laboratory animals with special reference to the effects of cold shock and the importance of calcium for the motility of hamster spermatozoa. Biol. Reprod. 3, 169-179.

Munro, S.S. (1938) Fowl sperm immobilisation by a temperature-media interaction and its biological significance. $Q$. Jl exp. Physiol. 27, 281-287.

Nevo, A.C. \& Schindler, H. (1968) Reversible inactivation of cock spermatozoa by temperature. Proc. 6th Int. Cong. Anim. Reprod. \& A.I., Paris II, 16371640.

Quinn, P.J., White, I.G. \& Voglmayr, J.K. (1970) The use of a continuous flow dialysis apparatus to determine the effects of cations, buffers and osmotic pressure on ram spermatozoa. J. Reprod. Fert, 22, 253-260.

Schulman, H. (1985) Phosphorylation of microtubuleassociated proteins by a $\mathrm{Ca}^{2+} /$ calmodulin-dependent protein kinase. J. Cell Biol. 99, 11-19.

Takeda, A. (1982) Studies on reversible inactivation of cock spermatozoa by temperature. Jap. Poult. Sci. $19,26-36$.

Tash, J.S. \& Means, A.R. (1983) Cyclic adenosine 3' $5^{\prime}$ monophosphate, calcium and protein phosphorylation in flagellar motility. Biol. Reprod. 28, 75-104.

Wishart, G.J. (1982) Maintenance of ATP concentrations in and fertilizing ability of fowl and turkey spermatozoa in vitro. J. Reprod. Fert. 66, 457-462.

Wishart, G.J. \& Palmer, F.H. (1986) Correlation of the fertilising ability of semen from individual male fowls with sperm motility and ATP content. Br. Poult. Sci. 27, 97-102.

Wishart, G.J. \& Ross, F.H. (1985) Characterisation of a spectrophotometric technique for the estimation of fowl and turkey sperm motility. Gamete Res. 11, 169178 .

Young, L.G. \& Nelson, L. (1974) Calcium ions and control of the motility of sea urchin spermatozoa. $J$. Reprod. Fert. 41, 371-378.

Received 2 December 1986 